\title{
The Burry-Man
}

\section{Isabel A. Dickson}

To cite this article: Isabel A. Dickson (1908) The Burry-Man, Folklore, 19:4, 379-387, DOI:

10.1080/0015587X.1908.9719842

To link to this article: http://dx.doi.org/10.1080/0015587X.1908.9719842

$$
\text { 曲 Published online: } 14 \text { Feb } 2012 .
$$

Submit your article to this journal ㄴ

Џll Article views: 1

Q View related articles $\sqsubset$ 


\section{$\mathfrak{J f o l k}=\mathfrak{T}$ ore.}

TRANSACTIONS OF THE FOLK-LORE SOCIETY.

\begin{tabular}{lll} 
Vor. XIX.] DECEMBER, Ig08. & [No. IV. \\
\hline
\end{tabular}

THE BURRY-MAN.

(With Plates VIII. and IX.)

BY ISABEL A. DICKSON.

(Read at Meeting, 15th April, 1908.)

ON the second Friday in August the annual fair is held at South Queensferry, a small burgh of great antiquity, just below the Forth Bridge. The fair takes place in a field within a convenient distance. (the burgh has now no common land of its own) and consists of the usual shows and merry-go-rounds with the recent addition of pipeplaying and reel-dancing. On the day before the fair, a house-to-house visitation is made by the Burry-man, a character who has existed from time immemorial. The ceremony is now left to the boys of the place, who make their rounds to collect money to be spent at the fair next day.

The Burry-man is a boy dressed in a tight-fitting suit of white flannel covered entirely with burrs stuck on. The covering goes over his whole body and partly over his face, so as to form a more or less efficient vol. $\mathrm{xIX}$. 
disguise. $\mathrm{He}$ is also adorned with flowers and ribbons, wears a head-dress of flowers, and carries in each hand a staff decorated with flowers and leaves. $\mathrm{He}$ is accompanied by two other boys in ordinary dress, who stand one on each side of him, supporting his outstretched arms and apparently guiding his movements. An interested group of children follow at a respectful distance, but only the Burry-man and his attendants come to the house. The asking is done by the attendants, the Burry-man maintaining a dignified silence. None of the attendants are decorated. I was informed that sometimes two Burry-men were led about and called the King and Queen, but this seems to be regarded as an unimportant variation.

In the photographs (1908) (Plates VIII. and IX.), the head-dress is a good deal larger and heavier than my recollection of it two years before, so that it covers more of the face.

As I learn by the courtesy of the Town-Clerk of South Queensferry, there are no documents or records bearing on the subject, but a description of the custom is given in the following quotations:

\section{Fyfe, Summer Life on Land and Water, p. 48, published $185 \mathrm{I}$.}

"A strange custom perpetuated to the present day among the youth of Queensferry, has been supposed to commemorate at once the passage of the King and Queen to and from Edinburgh and Dunfermline, and to indicate the civic origin of the place. We refer to the annual procession of the Burry-man, got up on the day preceding the Annual Fair amongst the boys of Queensferry, and traced back for time immemorial to the

${ }^{1}$ Mention is also made of the custom in Sinclair's Statistical Account (Linlithgow), 1845, and in Porteous' Town Council Seals of Scotland. 
PLATE VIII.

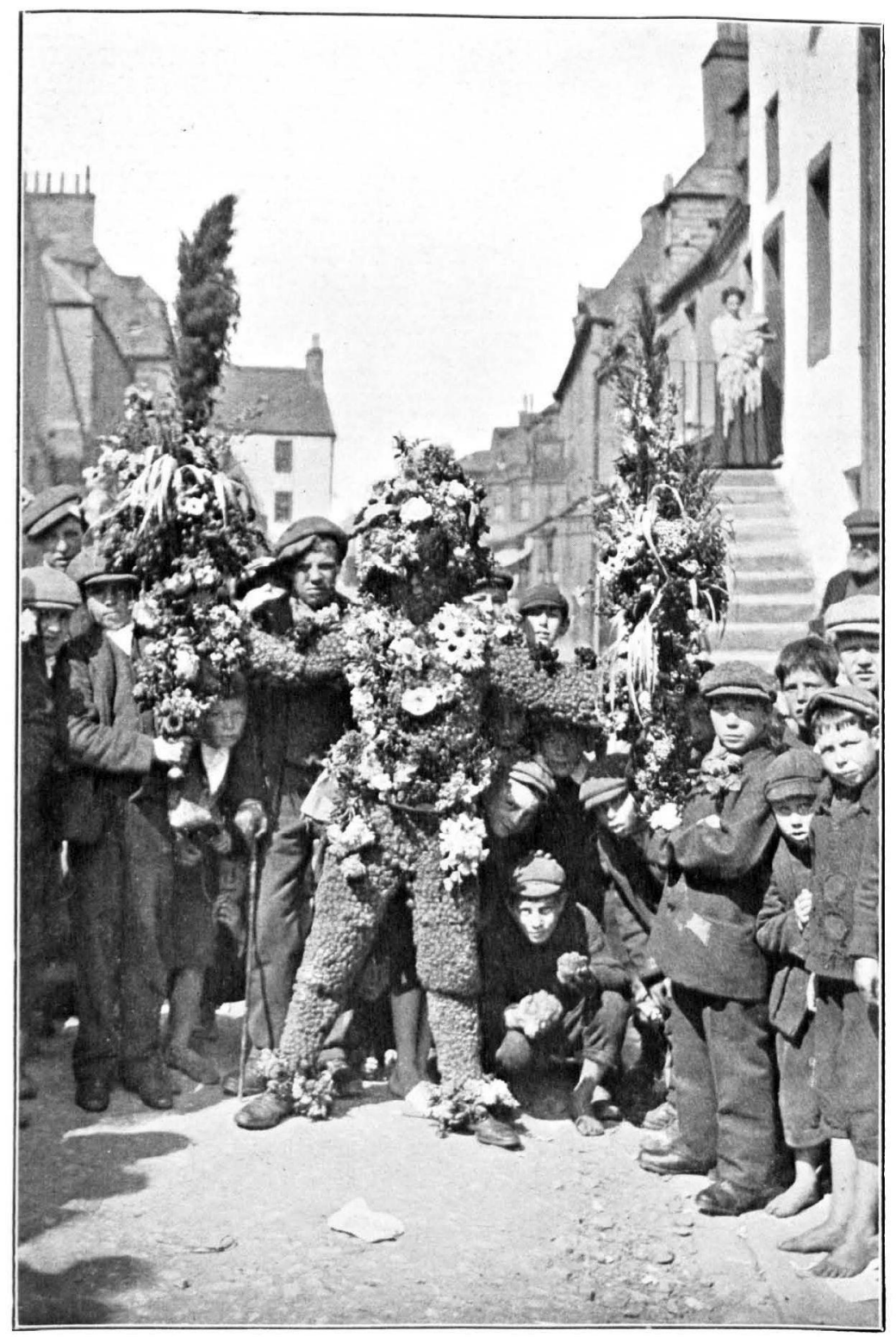

The Burryman. Front View

Lionardson a Co. 
Plate IX.

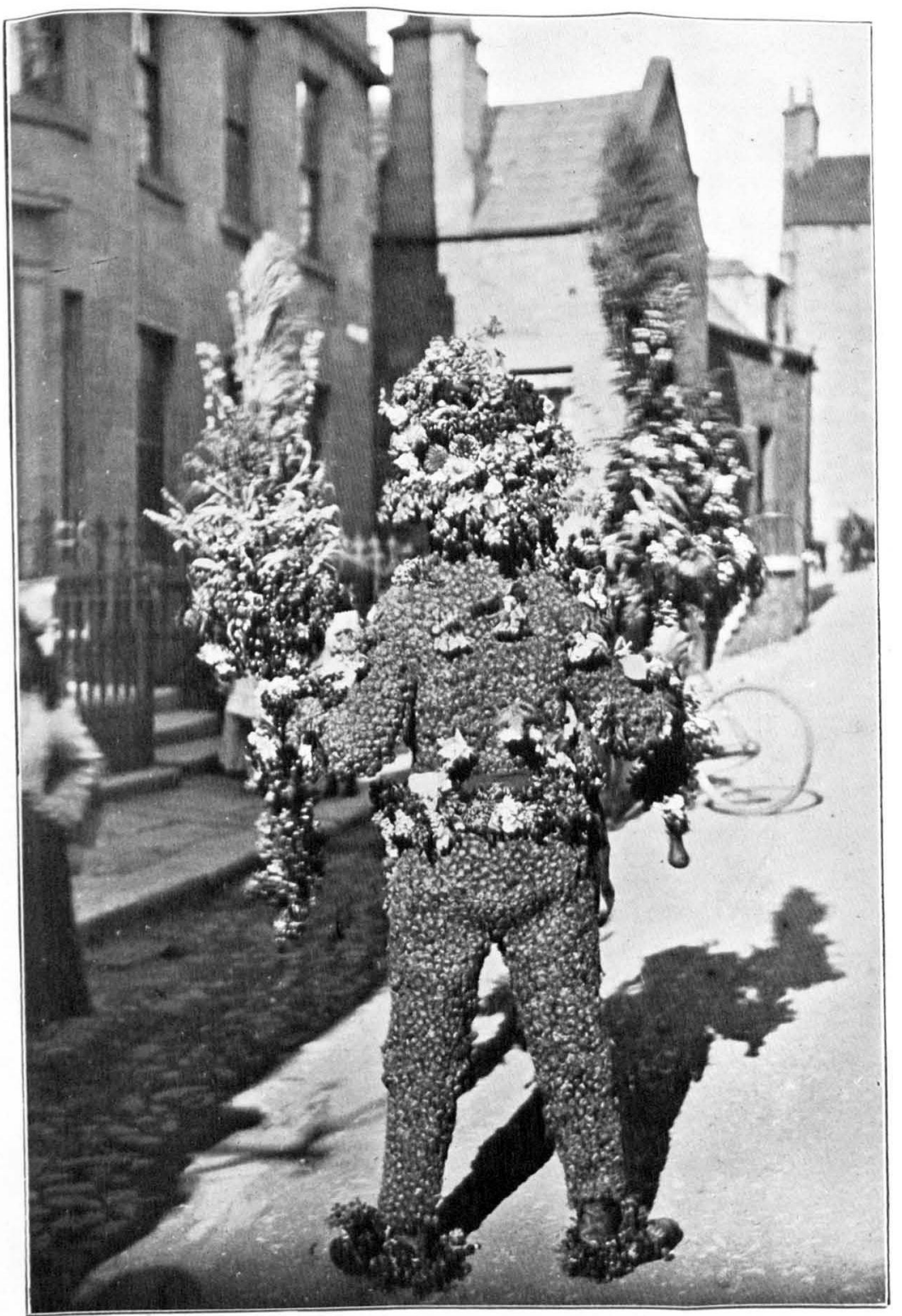

Leonardsus \& Co.

The Burryman. Back View. 
distraction of antiquarian research, tho' the hand of Sir Walter Scott has been tried on the subject. Of the latest representation of this little comedy we chanced to be an eyewitness, immediately after taking up our residence in Queensferry: and without reference to its historical bearing, we ventured to describe it from observation in the public prints of the day, somewhat as follows:

"The annual Saturnalia of the ancient port of passage across the Firth, of St. Margaret the Queen came off on Friday, 9th Aug., having been preceded on Thursday the 8th, according to ancient custom, by the singular perambulations of the Burry-man, i.e. a man or a lad loosely clad in flannels, stuck over with the well-known adhesive burrs of the Arctinus Bardana ${ }^{1}$ (the Burr Thistle of Burns, but in reality not a thistle but a burdock as botanists are aware). These burrs are found in considerable profusion at Blackness Point, in the vicinity of Hopetoun House. A few plants also grow in the neighbourhood of New Halls Point, and beyond the rocks of the opposite shore of North Queensferry, where we have found it on the Links near Inverkeithing, and from all these, or even more remote places are they gathered if necessary for this occasion, so essential are they deemed to the maintenance of this unique ceremony, the origin and object of which are lost in antiquity, and long ago foiled the antiquarian research of Sir Walter Scott. Tradition at present connects the custom with the erection of Queensferry into a royal borough which did not take place till the time of Charles I., and even points to the previous constitution as a burgh of regality, alleged to have originated under Malcolm Caenmohr, in which case the representation of the burgh by the Burry-man would amount to a whimsical practical pun. The custom in question can be traced back to the period of the last

${ }^{1}$ [Arctium Lappa? Ed.] 
battle of Falkirk, for an old person of 80 now living, whose deceased mother was aged I3 at the date of the battle (1746) states that the observation has remained unaltered from then till now.

"On the day preceding the fair, the Burry-man [who requires to be either a stout man or robust lad, as weakly persons, like the man in complete steel who annually sacrifices his life to the Lord Mayor's Show in London, have been known to faint under the heat and fatigue of dressing], is indeed in his flannels. Face arms and legs all being covered so as nearly to resemble a man in chain armour from the close adhesion of the burrs: and the head as well as the tops of two staves grasped with extended arms, being beautifully decked with flowers: while the victim thus accompanied is led from door to door by two attendants, who likewise assist in upholding his arms by grasping the staves. At every door in succession, a shout is raised, and the inhabitants, severally coming forth, bestow their kindly greetings and donations of money on the Burry-man who in this way collects, we believe, considerable sums to be eventually divided and spent at the fair by the youths associated in the exploit. Sometimes there are two persons thus decorated and led in procession from door to door, the one being styled the King, the other the Queen, in allusion to the passage of the royal party through the town."

Popular opinion now is divided between explaining Burry as meaning covered with burrs, or as a corruption of "burgh," with reference to the ancient burgh of South Queensferry. The whole festival, Burry man and Fair together, is supposed to commemorate the great event in the history of the burgh, which is also recorded on the town seal, namely, the crossing of the Firth of Forth and landing at South Queensferry by Margaret, wife of Malcolm Canmore. It is at once clear that whatever 
may be true of the Fair, the Burryman procession belongs to a stage of belief much older than Queen Margaret (eleventh century). The derivation from burgh may certainly be dismissed as arising out of the connection with Queen Margaret.

For other possible derivations, we have the following: Burs, burres is Scots for fir-cones, and in this sense is still used.

Burra is the name given in Orkney and Shetland to the common kind of rush-used for feeding sheep. ${ }^{1}$

Connected with this is Bear (Lancashire), name of a door-mat made of the peeling of rushes. Perhaps formerly these mats were made of bear-skin. The rough rope mat resembles one. ${ }^{2}$

Burry, or burrie, is an old Scots word used as an epithet of a dog, meaning rough, shaggy, and generally derived from the French bourru $=$ flockie, hairie. ${ }^{8}$

There is also a noun burris, meaning flocks or locks of wool, which is used in an Act of James VI. ${ }^{5}$

The green appearance of the Burryman and the bunches of leaves and flowers he carries are at once recognisable as signs of some nature cult connected with summer and the season of green and flowering things. Lammas ${ }^{6}$ has always been a very important season in Scotland, especially in country districts. It is, of course, the thanksgiving (the Loaf-mass), made from the fruits of the earth; but

\footnotetext{
IJam., Dict. Scot. Lang., ad loc. 2 Wright, Dialect Dict., ad loc.

"Jam., Dict. Scot. Lang., ad loc. 'Id.
}

"Miss Burne tells me that "Bur" in Shropshire means a rough unhewn stone. A "bur" wall is built of rounded unhewn stones. It is a sandstone district.

[In S.E. England generally the word 'burr' means a lump of fused brick from a kiln. (Ed.)]

- It is perhaps necessary to explain that though Lammas-day is Aug. 1, the term Lammas is used $=$ Lammas-tide. Cf. Christmas $=$ Christmas-tide. Cf. the proverbial Lammas floods which are expected in the first half of August. 
probably the special popularity of Lammas is due to its having coincided with or partially taken the place of an older nature festival, e.g. in Ireland and Wales the great festival of the God Lug took place on or about August 1st. ${ }^{1}$

In southern climates it would doubtless be quite possible to have a harvest thanksgiving on Lammas Sunday, but further north the harvest is much later, and at South Queensferry, for example, the corn might often not be cut before the end of August, so that to offer on Aug. Ist a loaf made from the new corn would be an absolute impossibility. Harvest thanksgiving, as generally understood now, is the Harvest Home, a thanksgiving for perils past; but there is another possible aspect of harvest sacrifice, that of propitiating a higher power, in order that no disaster may overtake the growing corn before it is ripened and harvested. This view would appeal at least as forcibly to the primitive agricultural mind as the other, though it is not one which could be recognised by the Christian Church. It would be in accordance with the ordinary spirit of compromise ${ }^{2}$ for the Christian festival of Lammas, harvest thanksgiving, officially to take the place of harvest propitiation, though the older custom, shorn of its real meaning, still flourished among the people.

The flowers and leaves which decorate the Burryman are rather a symbol of the luxuriant growth of summer than of harvest thanksgiving. There are numerous instances of such summer figures, e.g. near Willings-Hausen, Lower Hesse, a boy is covered over and over with leaves, green branches are fastened to his body: other boys lead him by a rope and make him dance as a bear, for doing which a present is given. ${ }^{3}$

${ }^{1}$ Rhỳs, Hibbert Lectures, p. 410 ; id. Welsh Folklore, i. 312.

2 Gregory to Abbot Meletus, 6or a.

' Grimm, Teut. Myth. ii. 784 ; cf. id. 764, 776, 783 . 
Curiously enough, the first glance at the South Queensferry Burryman, without any idea of comparison, made one think of a bear walking on its hind legs. This impression was strengthened by the fact that the burry covering coming down over the forehead and between the eyes practically concealed the upper part of the face. This resemblance may be only a coincidence (it is much less evident in the photograph), but it suggests the direction in which the explanation lies.

Burry then would be the old Scots word meaning shaggy or hairy, as given above. There seems no legend to explain the symbolic use of ordinary burs. Bur, in the sense of fir-cones, would have a reasonable connection with wood spirits, but this is still a common meaning of the word, and fir-cones have apparently never been part of the costume. But burry=shaggy is an old word, rare, and long out of use. The transference would not be unnatural, especially if the idea were to get a rough covering. At a distance, closely-set burs have somewhat the effect of locks of wool, in the same primitive fashion in which the stiff circles and holes of the pre-Pheidian Greek sculptors represent locks of hair. Similarly moss is used instead of fur in the dress of winter (Middle Rhine). ${ }^{1}$ In the same way the burry covering may be the survival of the fur dress, just as the Lancashire bear-mat may once have been a bear-skin.

There is little difficulty in finding instances of shaggy figures, either men or animals, possessing the power to work evil.

When Wolf Dieterich ${ }^{2}$ sets forth to ask the help of Ortnit of Lombardy, he is warned to beware in crossing the deserts of Roumelia, lest he be caught by Rauch Else. Losing his way in the forest, he is found by a dark and terrible monster of appalling height, black and shaggy like a bear, with a voice like a bear's growl. The hero's

\footnotetext{
1 Grimm, Teut. Myth. ii. 764. 2 Wagner, Legends of the Amelungs.
} 
promise to marry her breaks the spell, and the dark fleece falling off reveals the lovely princess. Cf. also the story of "Beauty and the Beast."

The same idea of a black shaggy horror appears in many old stories of haunting. ${ }^{1}$ Most people's childish recollections will bear witness to a shadowy bugbear, which was generally shaggy, sometimes black, sometimes both. As hobgoblins haunt dark corners, so shaggy monsters frequent forests and moors. The tradition is that Dalmeny ${ }^{2}$ means Black heaths or gloomy spots.

Mr. Frazer has shown that the corn spirit has many and varied animal forms, and there are many sayings to show its kindly fertilising action, e.g. "The steer is running in the corn," 8 when it is stirred by a gentle breeze. There are other proverbs showing the evil effect, e.g. when the wind has laid the growing corn: "See the wolf slept there last night." "

It is worth comparing with these a curious expression "to play the bear"=to damage, spoil, ruin. A market gardener in Northamptonshire" says: "A wet Saturday plays the bear with us." In Warwickshire " they say: "The pigs have been in the garden and played the bear with it."

Every farmer knows that the really fatal time "to play the bear with" the standing crop is after the corn is fully in the ear, and before it is ripened. After a rain or wind storm the heavier the crop the more difficult it is for the bent stalks to straighten themselves, and lying on the ground the ears ripen very imperfectly. It is therefore very important to make sure of divine protection at this stage, rather than to wait and offer thanksgiving after the dangerous time is over.

ICf Mauthe Dog in the Isle of Man.

- Till 1636 Queensferry was part of the parish of Dalmeny.

- Colden Bough, 277, 284.

- Mannhardt, ii. 322.

Wright, Diala Dict., ad loc.

- Id. 
In the legends of the Calydonian Boar, ${ }^{1}$ of Adonis, of Iphigenia, the untimely death, the destruction of the unripe is insisted on, clearly because propitiation for the safety of the growing crops of the young enterprise had been neglected. Later ethical development may make propitiation and thanksgiving into one festival, ${ }^{2}$ but untimely death could never apply to ripened corn.

In the case of Scotland, climate and circumstances would tend to give even longer life to the propitiatory idea. ${ }^{8}$ If the orthodox date for offering first fruits is a month before the corn can be gathered in, it is a little difficult for the ignorant mind to distinguish such a harvest thanksgiving from a placating sacrifice to ensure a good harvest.

I would therefore suggest that the ceremony of the Burryman is a relic of an early propitiatory harvest rite. The Burryman himself represents an indeterminate being, possibly the wild man of the woods, possibly the angry spirit in the form of wolf, bear or boar, whose original hairy shaggy covering has, by corruption or misunderstanding of the word burrie, degenerated into a covering of burrs. His procession and collection of money from door to door are the modern form of the sacrifice required to ensure a fruitful season.

ISABEL A. Dickson.

3 Hom. Il. ix. 534 .

${ }^{2}$ Harrison, Prolegomena, 79.

${ }^{3}$ There are at least two instances of openly propitiatory rites in Fife and Lothian in the thirteenth century, one conducted by the Parish Priest. Kemble, i. 356.

Note.-[It may also be suggested that the actual use of the burrs to form the shaggy covering may be due to a piece of popular etymology, an attempt to give a living meaning to the obsolete word 'burrie.' Ed.] 